\title{
Trade-offs between forest ecosystem services
}

\author{
Shuai Wang, Bojie Fu* \\ State Key Laboratory of Urban and Regional Ecology, Research Center for Eco-Environmental Sciences, Chinese Academy of Sciences, P. 0. Box 2871, Beijing 100085, PR China
}

\section{A R T I C L E I N F O}

Available online 9 November 2012

\section{Keywords:}

Forest

Ecosystem services

Trade-offs

Management

\begin{abstract}
A B S T R A C T
We are writing to comment on the article by Vihervaara et al. (2012) and the subsequent reply by Paruelo recently published on Forest Policy and Economics. Forests have long been recognized as the main ecological construction and restoration means for their multiple ecosystem services. But forests usually cannot simultaneously produce these multiple services due to the trade-offs among competing functions. These services have different spatial-temporal scale characteristics and corresponding different stakeholders. Rational management decisions depend on local conditions, needs, and underpinning ecosystem processes. The geographic differences could mask the true role of forests for the partitioning of rainfall into runoff and ET, producing different effects in arid and humid areas. Large-scale afforestation in the arid areas will undoubtedly result in water consumption, reducing the availability of runoff water. Therefore, this needs to be considered very cautiously. Pricing strategies are not sufficient for forest-water related issues, and inappropriate incentives will result in wasted water resources. It is necessary to integrate administration and human-values guidance for the sustainable management of forest ecosystem services.
\end{abstract}

(C) 2012 Elsevier B.V. All rights reserved.
The article by Vihervaara et al. (2012) recently published on Forest Policy and Economics assessed an important aspect of the ecosystem services management: stakeholder's valuation of the provision of ecosystem services resulted from land use transformation, and the subsequent reply by Paruelo (2012) make it more clear and comprehensive. However, the relationship between forest and water and its feature of spatial/temporal scale dependence need to be further addressed. Both Vihervaara et al. (2012) and Paruelo (2012) were aware that forests are among the most important providers of ecosystem services for environmental rehabilitation, biodiversity maintenance, carbon sequestration, bio-fuel, timber production, amenity, and social benefits (Calder, 2007; Deal and White, 2012). But forests usually cannot simultaneously produce these multiple, positive ecosystem services due to the trade-offs among different, or even competing functions; maximizing one service may cause substantial declines in other services (Bennett et al., 2009). Specifically, the trade-off between water supply and carbon sequestration has attracted more attention in recent years due to climate change (Jackson et al., 2005); however, the debate on the relationship between forest cover and water yield does not yet have a definite conclusion. Thus, to maximize the production of forest ecosystem services, one must understand the underpinning driving processes to avoid the risk of unwanted trade-offs and help take advantage of synergies. The review, "On the forest cover-water yield debate: from demand-to supply-side thinking" by David Ellison et al., which appeared in a recent issue of Global Change Biology

\footnotetext{
* Corresponding author. Tel./fax: + 861062923557.

E-mail address: bfu@rcees.ac.cn (B. Fu).
}

(2012) discussed the beneficial relationship between forest cover and the intensity of the hydrologic cycle from the supply side. It is very innovative, but we believe that is not comprehensive, and there are still several points to take note of.

Forests have been recognized for a long time as playing an important role in providing clean water (Townsend et al., 2012). For example, in the U.S., it is estimated that about $80 \%$ of the freshwater resources originate from forests, which cover about one-third of the nation (USDA Forest Service, 1999). It should be noted that this does not mean forests can produce clean water; forests actually interacted with water mutually, and plenty of water also raise the forests. Both from the supply and demand sides, forests affect the hydrological cycle, mainly through the evapotranspiration (ET) process. Zhang et al. (2001) postulated that the average ET amount of a catchment or region depends upon the minimum value of potential evaporation (PET) and available water (AW) for evaporation. Wang et al. (2011) argued that forests could enhance the complementary relationship between ET and PET, so the greater amount of ET in forested areas might decrease the PET at the regional scale. This can be evidenced by the collected catchment datasets of China; 65 annual catchment observations of forest covers and PET show there was a significantly negative relationship between them $(r=-0.74, p<0.05)$ (Wang et al., 2011). Thus, according to the water-balance equation $(\mathrm{P}=\mathrm{ET}+\mathrm{R})$, afforestation or reforestation campaigns could enhance the runoff partitioning ratio from precipitation on average, to a certain degree, in humid areas. In an area such as Uruguay where the annual mean precipitation was in the range of 1300-1400 mm, as Paruelo (2012) summarized tree plantation would consume $80 \%$ more water than grasslands, reduce the water yield and even the ground water level. However, this negative 
consequence was not reflected in the local people's perceptions investigated by Vihervaara et al. (2012).

As David Ellison et al. (2012) pointed out, the distinction between the demand and supply side is from a different thinking scale. The conclusions made at different scales are often incomparable, because they reveal different phenomena within the same entity. Linking these different scales has become a major challenge in all sciences (Schymanski, 2008). Thus, from the so-called from-demand-to-supplyside thinking are different ways that the same ecological process, evapotranspiration is expressed at different scales, local and regional. Most of the ecosystem-services trade-offs were the consequences of scale mismatch between ecosystem-process operation and social decisions (Rodriguez et al., 2006). Different ecosystem services underpinned by the same process provide the benefit or variety of benefits with its own spatial and temporal scales, corresponding to different stakeholders. In case of the industrial tree plantations in South America, this is also the reason that resulted in conflicts generated at the local, national and international levels (Paruelo, 2012). As Vihervaara et al. (2012) pointed out local stakeholders gave little emphasis on the impact of plantation on biodiversity and ecosystem degradation, particularly for the carbon sequences, but all of these are extremely important at the global or regional level. For the forest and water, the demand side is for the local scale and the supply side is appropriate for the regional to global scales. Therefore, if we maximize the total precipitation for regional or global stakeholders, this often results in substantial declines in the water provision for the locals, and vice versa. These trade-offs also deteriorate the sustainability of the whole social-natural system. More importantly, the increased precipitation resulting from the forest's evapotranspiration will not always fall in the places that need water, or may even cause flooding in humid areas. For example, in the past three decades, a series of large reforestation campaigns have led to forest cover increases from $6.5 \%$ in the 1970 s to 51.13\% in 2010 on the Loess Plateau of China. However, the precipitation is decreasing and the drought intensified (Wang et al., 2012).

Ecosystem services are benefits that people obtained from ecosystems; as Paruelo (2012) concluded ecosystem services are an anthropogenic concept, in the absence of people there are no services (Bennett et al., 2009), therefore local stakeholders' perception is critical for ecosystem services assessment and management (Kijazi and Kant, 2010; Vihervaara et al., 2012). From the perspective of ecosystem services, we can see what the forest has done for humans or a certain section of people, not the actual comprehensive performance of forests. Thus, the valuation and water-pricing strategies for forests, both from the demand or supply side, will certainly be developed with a lot of subjectivity and uncertainty. Lack of a clear picture of water's biophysical factors and processes that support the targeted services, incentives based on one-sided judgment could actually accelerate environmental degradation (Palmer and Filoso, 2009), same as the carbon market for tree plantation in Uruguay (Paruelo, 2012). As the forest could enhance ET and intensify the hydrological cycle to provide precipitation as a public good, other water-consumption activities like agriculture irrigation also could produce large amounts of ET, especially in the arid areas; however, this is likely to cause a shortage of water resources. On the Loess Plateau, large-scale forest restoration aggravated water scarcity, and gradually led to soil desiccation in the deep soil layer. This resulted in low yield and efficiency, and "small aged trees" with heights of 3-5 m appeared widely (Chen et al., 2008).

Forests have long been recognized as the main ecological construction and restoration means for their multiple ecosystem services (Deal et al., 2012). These services have different spatial-temporal scale characteristics and corresponding different stakeholders. In order to make rational management decisions, we depend on local conditions, needs, and underpinning ecosystem processes. The geographic differences could mask the true role of forests for the partitioning of rainfall into runoff and ET, producing different effects in arid and humid areas (Wang et al., 2011). Large-scale afforestation in the arid areas will undoubtedly result in water consumption, reducing the availability of runoff water. Therefore, this needs to be considered very cautiously. Pricing strategies are not sufficient for forest-water-related issues, and inappropriate incentives will result in wasted water resources. It is necessary to integrate administration and human-values guidance for the sustainable management of forest ecosystem services.

\section{Acknowledgments}

The research was supported by the State Forestry Administration of China (no. 201004058), the National Basic Research Program of China (no. 2009CB421104), the External Cooperation Program of the Chinese Academy of Sciences (no. GJHZ1215), and the CAS/SAFEA International Partnership Program for Creative Research Teams of "Ecosystem Processes and Services".

\section{References}

Bennett, E.M., Peterson, G.D., Gordon, L., 2009. Understanding relationships among multiple ecosystem services. Ecology Letter 12, 1394-1404.

Calder, I.R., 2007. Forests and water-ensuring forest benefits outweigh water costs Forest Ecology and Management 251, 110-120.

Chen, H.S., Shao, M.A., Li, Y.Y., 2008. Soil desiccation in the Loess Plateau of China. Geoderma 143, 91-100.

Deal, R.L., White, R., 2012. Integrating forest products with ecosystem services: a global perspective. Forest Policy and Economics 17, 1-2.

Deal, R.L., Cochran, B., LaRocco, G., 2012. Bundling of ecosystem services to increase forestland value and enhance sustainable forest management. Forest Policy and Economics 17, 69-76.

Ellison, D., Futter, M., Bishop, K., 2012. On the forest cover-water yield debate: from demand-to supply-side thinking. Global Change Biology 18, 806-820.

Jackson, R.B., Jobbagy, E.G., Avissar, R., Roy, S.B., Barrett, D.J., Cook, C.W., Farley, K.A., le Maitre, D.C., McCarl, B.A., Murray, B.C., 2005. Trading water for carbon with biological sequestration. Science 310, 1944-1947.

Kijazi, M.H., Kant, S., 2010. Forest stakeholders' value preferences in Mount Kilimanjaro, Tanzania. Forest Policy and Economics 12, 357-369.

Palmer, M.A., Filoso, S., 2009. Restoration of ecosystem services for environmental markets. Science $325,575-576$.

Paruelo, J.M., 2012. Ecosystem services and tree plantations in Uruguay: a reply to Vihervaara et al. (2012). Forest Policy and Economics. http://dx.doi.org/10.1016/ j.forpol.2012.04.005.

Rodriguez, J.P., T.D.B, Bennett, E.M., Cumming, G.S., Cork, S., Agard, J., Dobson, A.P., Peterson, G.D., 2006. Trade-offs across space, time, and ecosystem services. Ecology and Society $11,28$.

Schymanski, S.J., 2008. Optimality as a concept to understand and model vegetation at different scales. Geography Compass 5, 1580-1598.

Townsend, P.V., Harpera, R.J., Brennan, P.D., Dean, C., Wu, S., Smettem, K.R.J., Cook, S.E 2012. Multiple environmental services as an opportunity for watershed restoration. Forest Policy and Economics 17, 45-58.

USDA, 1999. Roads Analysis: Informing Decisions About Managing the National Forest Transportation System. FS-643. Washington, DC.

Vihervaara, P., Marjokorpi, A., Kumpula, T., Walls, M., Kamppinen, M., 2012. Ecosystem services of fast-growing tree plantations: a case study on integrating social valuations with land-use changes in Uruguay. Forest Policy and Economics 14, 58-68.

Wang, S., Fu, B.J., He, C.S., Sun, G., Gao, G.Y., 2011. A comparative analysis of forest cover and catchment water yield relationships in northern China. Forest Ecology and Management 262, 1189-1198.

Wang, S., Fu, B.J., Gao, G.Y., Yao, X.L., Zhou, J., 2012. Soil moisture and evapotranspiration of different land cover types in the Loess Plateau, China. Hydrology and Earth System Science 16, 2883-2892.

Zhang, L., Dawes, W.R., Walker, G.R., 2001. The response of mean annual evapotranspiration to vegetation changes at catchment scale. Water Resources Research 37, 701-708. 